\title{
Protective Effects of Palm Date and Apricot Kernels Powder in Carbon Tetra Chloride-Induced Liver Disorder in Rats
}

\begin{abstract}
Zeinab S.A. Ahmed
Home Economic Dept., Nutrition and Food Science, Faculty of Specific Education, Assiut University, Egypt.
\end{abstract}

\begin{abstract}
Effects of some levels 2.5 and $5 \%$ of apricot, palm date kernels and their mixture as powder on biological and biochemical changes of hepatic rats were evaluated. Forty-eight white male albino rats weighing $140 \pm 10 \mathrm{~g}$ were used in this study. Rats divided to 8 groups, each group (6) rats. Hepatotoxicity was induced in rats by injecting carbon tetrachloride $\left(\mathrm{CCl}_{4}\right) 0.2 \mathrm{ml} / 100 \mathrm{~g}$ body weight of $40 \mathrm{ml} / 1 \mathrm{CCl}_{4}$ dissolved in paraffin oil. Identification of phenolic compounds was determined using HPLC technique, serum liver Enzyme such as alanine aminotransferase (ALT), aspartate aminotransferase (AST), total cholesterol (TC), triglycerides (TG), high density lipoprotein cholesterol (HDLc), low density lipoprotein cholesterol (LDL-c), very low density lipoprotein cholesterol (VIDL-c), kidney functions (uric acid, urea and creatinine), oxidative enzymes such as glutathione peroxidase (GSH-Px), superoxide dismutase (SOD) and catalase (CAT) activity were also determined. The obtained results of hepatic rats indicated that apricot, palm date kernels powder and their mixture improve serum liver functions, kidney functions, lipids profile and oxidative enzymes in rats especially 5\% mixture of apricot and palm date kernels powder. The HPLC results showed that the apricot kernels contained higher bioactive compounds than palm date. Results also indicated that mixture of apricot, palm date kernels powder recorded the best treatment for improved all tested biochemical analysis. Therefore, apricot and palm kernels powder and their mixture could be used in our beverages and daily dishes, because it has so many health benefits.
\end{abstract}

Key words: apricot kernels and palm date kernels, Rats, protective effect and Biochemical analysis. 


\section{Introduction}

The liver is the chief and the most important metabolic organ of the human body. It performs more than 500 essential functions like conversion from food components to critical blood components, vitamin and mineral storage, the production of many essential plasma proteins and minerals, the maintenance of hormone levels and metabolic rate, and the detoxifying of body toxic waste. It secretes bile that helps in lipid digestion (Ghany and Hoofnagle, 2005). Further, it is responsible for synthesizing the blood-clotting factors prothrombin, fibrinogen; and heparin, which prevents the blood from clotting within the blood circulation. In addition, Liver is noteworthy in functions such as metabolisms of lipids, proteins, and carbohydrates. The liver helps in regulating the normal glucose concentration during fasting (Vuda et al., 2012). Any clinical defects or conditions which rise to impairment of liver are known as liver diseases. Hepatic diseases are categorized primarily into two types: acute and chronic liver diseases. The acute liver disease occurs rapidly and usually exists for a very short duration. Chronic liver disease is typically long-term, usually in excess of 6 months. In the clinical circumstances, the chronic disease causes periodical destruction and regeneration of liver parenchyma generates fibrosis and cirrhosis of the liver (Crawford, 2007).

Currently, hepatotoxicity is the most common pathology in the world, representing up to 83 per cent of all cases and the most serious health problems. Free radicals and reactive oxygen species, independent of the original causative agent, are increasingly believed to play a crucial role in the initiation and progression of liver diseases. Carbon tetrachloride $\left(\mathrm{CCl}_{4}\right)$ is a selective hepatotoxic chemical agent that is synthesized by the cytochrome $\mathrm{P} 450$ into highly reactive metabolites including trichloromethyl free radical $\left(\mathrm{CCl}_{3}{ }^{\bullet}\right)$ and trichloromethylperoxy radical $\left(\mathrm{CCl}_{3} \mathrm{O}_{2} \bullet\right)$ (Al-Harbi et al., 2014).

Ganesan et al., (2018) reported that dietary management tenders a realistic alternative for prevention and healing of various hepatic diseases. The amount and composition of the food and the intake frequency could affect the progression or prevention of pathological conditions. Bioactive food components are nonessential biomolecules, extensively present in diets and show the capability to control more than one metabolic pathway, which helps to give beneficial effects for several diseases and target tissues in humans. In plants, it is widely present in the forms of alkaloids, phytosterols, organosulfur compounds, carotenoids, polyphenols and nitrogen containing compounds.

Apricot, (Prunus armeniaca, L.) is a member of the Rosacea, subfamily Prunoideae. Apricot is one of the most common crops worldwide, being a good source of nutrients. The apricot kernel is an essential dietary 
protein source, as well as oil and fiber. Reportedly, the kernel also has high antioxidant and antimicrobial activity. Apricot kernels are mainly used in the production of oils and benzaldehyde; kernels are also added to bakery products either whole or grounded, and are also consumed as an appetizer. The percentage of the kernel of apricot varies from 18.8 to $38.0 \%$. The chemical constituents of apricot kernels appeared that the protein content of apricot kernels ranged from 14.1 to $45.3 \%$, carbohydrate $25.5-31.5 \%$, fat from 27.7 to 66.7\% and ash from 1.9-2.7\%, respectively (Alpaslan and Hayta, 2006). Apricot kernels are generally produced in many Mediterranean regions, Turkey exported to European countries and used especially in medicine, cosmetic and oil production. Apricot kernels, especially rich in lipids and proteins, are potentially useful for human nutrition, along with large amounts of oil and fiber (Abdel-Rahman, 2011). On the other hand, Dicenta et al., (2002) reported being a major component of apricot kernels, bitter almonds and peach, plum, pear and apple seeds. It is reported that apricot seeds and bitter almonds contain approximately $20-80 \mu \mathrm{mol} / \mathrm{g}$ and $100 \mu \mathrm{mol} / \mathrm{g}$ of amygdalin, respectively. However, research on the ability of bitter apricot kernel to help protect the liver and improve liver function is insufficient.

Egypt is considered one of the date-producing countries. The fruit of the date palm is composed of a fleshy pericarp and seed, and the seed represents about $15 \%$ of the total weight of the date fruits. These date seeds (named also, pits, stones, kernels) are waste products from date industry which can be used as a functional feed ingredient because they are a good source of dietary fiber, phenolic compounds and antioxidant activity in addition to a considerable amount

of feed ingredients such as protein and minerals (Ahmed et al., 2008). The palm date kernels contains $3.1-7.1 \%$ moisture, $2.3-6.4 \%$ protein, 5.0-13.2 fat, $0.9-1.8 \%$ ash and $22.5-80.2 \%$ dietary fiber. Also, seeds contain high levels of phenolic (3102- $4430 \mathrm{mg}$ Gallic acid equivalents/ $100 \mathrm{~g}$ ), antioxidants and dietary fiber (78-80 g/100 g) (Al-Farsi et al., 2007).

In traditional Egyptian medicine, date palm (Phoenix dactylifera, L.) seeds are listed in folk remedies for the management of diabetes, liver diseases, gastrointestinal disorders and. many pathological conditions (Vayalil, 2012).

This work was conducted to study the effect of different concentrations of apricot, palm date kernels and their mixture as powder on biological and biochemical changes of hepatic fibrosis rats. 


\section{Material and methods}

\section{Materials}

\section{Palm date and apricot kernels}

Commercially fresh and ground apricot fruit (Prunus armeniaca, L), palm date fruit (Phoenix dactylifera, L.) were obtained from local market in 2019 at Assiut Governorate, Egypt.

\section{Chemicals and chemical kits:}

Pure white crystalline cholesterol powder, saline solutions casein, cellulose, choline chloride powder, and DL methionine powder, were obtained from Morgan Co. Cairo, Egypt. Chemical kits used in this study (Total cholesterol, Triglycerides, high density lipoprotein, alanine amino transferase, aspartate amino transferase, alkaline phosphatase, urea, uric acid, and creatinine (TC, TG, HDL-C, ALT, AST, ALP,) were obtained from Al-Gomhoria Company for Drugs, Chemical and Medical Instruments, Cairo, Egypt. While, GSH, CAT, SOD kits were obtained from SIGMA Chemical Co., Cairo, Egypt.

Carbon tetrachloride $\left(\mathbf{C C l}_{4}\right)$ was obtained from Morgan Chemical Factory, Cairo, Egypt.

\section{Experimental animals}

A total of 48 adult normal male albino rats Sprague Dawley strain weighing $140 \pm 10 \mathrm{~g}$ was obtained from Vaccine and Immunity Organization, Ministry of Health, Helwan Farm, Cairo, Egypt.

\section{Methods}

\section{Preparations of apricot and palm date kernels}

To prepare the dried powder of apricot and palm kernels. Fruits were washed thoroughly under running tap water, then kernels were removed from fruits, kernels were shade and dried in an air oven at $50 \mathrm{C}$ for $24 \mathrm{hr}$., and ground to obtain fine powder using an air mill according to the method described by Femenia et al., (1995).

\section{Identification of phenolic compounds:}

HPLC analysis of extracts was performed using an Agilent 1200 chromatograph equipped with a PDA model G1315B, a Bin pump odel G1312A, an auto-sampler model G1313A and a RR Zorbax Eclipse Plus C18 column $(1.8 \mu \mathrm{m}, 150 \mathrm{~mm} \times 4.6 \mathrm{~mm})$. The HPLC method was used according to Radovanović et al., (2010) with some modification (elution gradient and flow rate). 


\section{Experimental design and animal groups \\ The induction of hepatic fibrosis in rats}

Rats were injected subcutaneously at a dose of $0.2 \mathrm{ml} / 100 \mathrm{~g}$ body weight of $40 \mathrm{ml} / 1 \mathrm{CCl}_{4}$ dissolved in paraffin oil (Diao et al., 2011). Carbon tetrachloride was injected three times per week for 4 consecutive weeks. Liver fibrosis was determined at the end of experimental with histopathological examination.

\section{Experimental design}

Forty-eight adult male white albino rats, Sprague Dawley Strain, 10 weeks' age, weighing $(140 \pm 10 \mathrm{~g})$ were used in this experiment. All rats were fed on basal diet (casein diet) prepared according to Reeves et al., (1993) for 7 consecutive days for adaptation. After this adaptation period, rats were divided into 6 groups, six rats per each as follows: group (I): rats fed on basal diet as negative control. Group (2): Hepatotoxic rats injected by $0.2 \mathrm{ml} / 100 \mathrm{~g}$ body weight of (40 $\mathrm{ml} / \mathrm{l} \mathrm{CCl}_{4}$ ) (Morgan Chemical Factory, Egypt) dissolved in paraffin oil (Dong et al., 2005). Carbon tetrachloride was injected three times per week for 6 consecutive weeks and used as a positive control group. Group (3): Hepatotoxic rats fed on basal diet supplemented with apricot kernels as powder by $2.5 \%$ of diet. Group (4): Hepatotoxic rats fed on basal diet supplemented with apricot kernels as powder by $5 \%$ of diet Group (5): Hepatotoxic rats fed on basal diet supplemented with the palm date kernels $2.5 \%$ of diet. Group (6): Hepatotoxic rats fed on basal diet supplemented with the palm date kernels 5\% of diet. Group (7): Hepatotoxic rats fed on basal diet supplemented with the mixture (1:1) of apricot and palm date kernels $2.5 \%$ of diet. Group (8): Hepatotoxic rats fed on basal diet supplemented with the mixture (1:1) of apricot and palm date kernels $5 \%$ of diet. The experiment continued for 28 days, at the end of the experimental period each rat weight separately then, rats were slaughtered and blood samples collected.

\section{Blood sampling}

After fasting for 12 hours, blood samples were obtained from hepatic portal vein at the end of each experiment. The blood samples were collected into a dry clean centrifuge glass tubes and left to clot in water bath $\left(37^{\circ} \mathrm{C}\right)$ for 30 minutes, then centrifuged for 10 minutes at $4000 \mathrm{rpm}$ to separate the serum, which were carefully aspirated and transferred into clean cuvette tube and stored frozen in deep freezer till analysis Schermer, (1967). 


\section{Biochemical analysis}

\section{Liver Enzymes}

Determination of serum alanine aminotransferase (ALT), serum aspartate aminotransferase (AST), serum alkaline phosphatase (ALP) were carried out according to the method of Clinica Chimica Acta, (1980), Hafkenscheid (1979) and Moss (1982), respectively.

Serum lipids profile

Serum total cholesterol was determined according to the colorimetric method described by Thomas (1992). Serum triglycerides were determined by enzymatic method using kits according to Young, (1975) and Fossati \& Principle, (1982). HDL-c was determined according to the method described by Friedwaid (1972) and Grodon \& Amer (1977).

VLDL-c was calculated in $\mathrm{mg} / \mathrm{dl}$ according to Lee and Nieman (1996) was using the following formula: VLDL-c $(\mathbf{m g} / \mathbf{d l})=$ Triglycerides $/ 5$

LDL-c was calculated in $\mathrm{mg} / \mathrm{dl}$ according to Lee and Nieman (1996) as follows:

LDL-c $(\mathrm{mg} / \mathrm{dl})=$ Total cholesterol - HDL-c - VLDL-c

Kidney functions

Serum urea was determined according to the enzymatic method of Patton and Crouch, (1977). Serum uric acid was determined calorimetrically according to the method of Barham and Trinder (1972). Creatinine was determined according to kinetic method of Henry, (1974).

Determination of enzyme activities

Determination of catalase (CAT) activity

Liver catalase (CAT) was determined by Goth's colorimetric method, according to the method described by Goth, (1991).

Determination of superoxide dismutase (SOD) activity

Superoxide dismutase (SOD) activity was determined by using a measurement method developed by McCord and Fridovich, (1969).

Determination of glutathione peroxidase (GSH-Px) activity

Glutathione peroxidase (GSH-Px) activity was measured on standard assay conditions in $340 \mathrm{~nm}$ (absorbance) at $37^{\circ} \mathrm{C}$ according to the method developed by Paglia and Valentine (1967).

\section{Statistical analysis}

The data were analyzed using a completely randomized factorial design SAS, (1988) when a significant main effect was detected. The means were separated with the LSD Test. Differences between treatments at $\mathrm{P} \leq 0.05$ were considered significant using Costat Program. Biological results were analyzed by One Way ANOVA. 


\section{Results and discussion}

\section{Identification of phenolic compounds of palm date and apricot kernels}

Results tabulated in Table (1) showed the identification of phenolic compounds of apricot and palm date kernels by HPLC technique. The obtained results indicated that the highest phenolic compounds identified in apricot kernels recorded for chlorogenic acid, quercetin and gallic acid. The values were $917.00,12.60$ and $4.90 \mathrm{mg} / 100 \mathrm{~g}$, respectively. On the other hand, the lowest phenolic compounds identified in apricot kernels recorded for caffeic acid, ferulic acid and vanillin. The values were $0.70,1.40$ and $1.65 \mathrm{mg} / 100 \mathrm{~g}$, respectively.

In case of palm date kernels, data indicated that the highest phenolic compounds identified in palm date kernels recorded for Gallic acid, rutin and $(+)$-catechin. The values were $14.80,8.50$ and $7.68 \mathrm{mg} / 100 \mathrm{~g}$, respectively. On the other hand, the lowest phenolic compounds identified in palm date kernels recorded for vanillic acid, syringic acid and $p$-coumaric acid. The values were $0.30,0.83$ and $1.95 \mathrm{mg} / 100 \mathrm{~g}$, respectively. These results are in agreement with Ugur et al., (2018); they reported that the major phenolic compounds of apricot kernels were chlorogenic acid and rutin. Other phenolic compounds included catechin and its derivatives, naringin and its derivatives, and also caffeic acid. Also, Saleh et al., (2011); they stated that the phenolic compounds of palm date were catechin $(r=0.96)$, and rutin $(r=0.74)$ in water extract, whereas this correlation significantly reduced in alcoholic extract $(\mathrm{r}=0.66)$ for catechin and also very weak $(r=0.38)$ for rutin.

\section{Effect of palm date, apricot kernels powder and their mixtures on liver function of hepatic fibrosis rats}

Results given in Table (2) show the effect of palm date, apricot kernel and their mixtures on ALT, AST level of hepatic rats. The obtained results indicated that ALT liver enzyme of positive control rats group recorded the higher value when compared with negative control group with a significant difference at $(\mathrm{P} \leq 0.05)$. The mean values were $93.50 \pm 0.35$ and $47.20 \pm 0.10 \mathrm{U} / \mathrm{L}$, respectively. While, the mean values of treated groups (hepatic rats) G3, G4, G5, G6, G7 and G8 were lower than positive control group, which were $65.50 \pm 0.45,60.00 \pm 0.30$, $59.50 \pm 0.15,54.00 \pm 0.60,52.00 \pm 0.50$ and $49.30 \pm 0.40$ (U/L), respectively. Rats fed on (G8) 5\% mixture palm date and apricot showed non-significant difference as compared with negative control group and recorded the best treatment.

On the other hand, the AST liver enzyme of positive control rats group recorded the higher value when compared with negative control group with a significant difference at $(\mathrm{P} \leq 0.05)$. The mean values were $105.0 \pm 0.40$ and 
$50.10 \pm 0.80 \mathrm{U} / \mathrm{L}$, respectively. The mean value of treated groups (hepatic fibrosis rats) G3, G4, G5, G6, G7 and G8 were lower than positive control group with a significant difference, which were $86.50 \pm 1.20,80.0 \pm 0.50$, $76.85 \pm 0.90,68.50 \pm 0.60,59.35 \pm 0.60$ and $53.75 \pm 0.60$ (U/L), respectively. The best result was recorded for (G8) rats fed on $5 \%$ palm date and apricot kernels mixture.

Ohta et al., (2004) Reported that carbon tetrachloride $\left(\mathrm{CCl}_{4}\right)$ is a highly toxic chemical agent which is used as an industrial solvent. $\mathrm{CCl}_{4}$ is widely used to induce hepatic steatosis and to study the effects of protective agents, especially antioxidants. There has been detailed study of CCl4's toxic effects on the liver. Metabolic activation of $\mathrm{CCl}_{4}$ by cytochrome $\mathrm{P} 450$ to free radicals, namely trichloromethyl peroxy radicals, is reported to increase lipid peroxidation and protein oxidation in the liver, resulting in widespread damage to the membranes and injury to the liver. Metabolic activation of $\mathrm{CCl}_{4}$ by cytochrome $\mathrm{P} 450$ to the free radicals, namely trichloromethyl proxy radicals, is reported to enhance lipid peroxidation and protein oxidation in the liver, resulting in widespread membrane damage and liver injury. Membrane damage also causes alterations in lipoprotein secretion and lipoprotein and lipid droplet accumulation in hepatocytes.

These results are supported by Abdel-Rahman (2011) who demonstrated that ground apricot kernel (GAK) administration specifically (1.5 $\mathrm{mg} / \mathrm{kg} / \mathrm{BW} / \mathrm{rat}$ ) can effectively improve liver fibrosis caused by DMN, and can be used as a hepatic fibrosis treatment option and prevention measures. The act of why high amounts of GAK was improved biochemical values as compared to low or moderate levels tested in this study may be due to increased levels of oleic acid and other phenolic compounds in apricot kernels. Also, Abdul-Aziz and Ali, (2014), reported that the dates palm (Phoenix dactylifera) seeds could be a promising and could be attributed to antioxidant and free radical scavenging. El-Far et al., (2016) stated that a significant reduction in elevated ALT, AST, and alkaline phosphatase (ALP) activates due to $\mathrm{CCl}_{4}$ in rats subjected to both pre- and post-treatments with the aqueous extracts of $P$. dactylifera fresh and seeds.

It's improved the $\mathrm{CCl}_{4}$-induced alterations in liver function parameters (AST, ALT, ALP and albumin) and this hepatoprotective effect might be attributed to the antioxidant and free radical scavenging activities.

\section{Effects of palm date, apricot kernels powder and their mixtures on serum total cholesterol and triglycerides of hepatic fibrosis rats}

The effect of palm date, apricot kernels and their mixtures on total cholesterol and triglycerides of hepatic fibrosis rats are shown in Table (3). It is clear to notice that the total cholesterol of positive control group recorded the 
higher value when compared with negative control group with a significant difference at $(\mathrm{P} \leq 0.05)$. The mean values were $130.0 \pm 1.40$ and $95.0 \pm 0.10 \mathrm{mg} / \mathrm{dl}$, respectively. The mean value of treated groups (hepatic fibrosis rats) G3, G4, G5, G6, G7 and G8 were lower than positive control group with a significant difference, which were $119.0 \pm 0.30,112.0 \pm 0.10,116.0 \pm 0.30,109.0 \pm 0.40$, $110.0 \pm 0.20$ and $101.0 \pm 0.30 \mathrm{mg} / \mathrm{dl}$, respectively.

In the other hand, the triglycerides levels of positive control group recorded the higher value when compared with negative control group with significant difference at $(\mathrm{P} \leq 0.05)$. The mean values were $100.00 \pm 2.21$ and $63.0 \pm 0.20 \mathrm{mg} / \mathrm{dl}$, respectively. The mean values were $130.0 \pm 1.40$ and $95.0 \pm 0.10 \mathrm{mg} / \mathrm{dl}$, respectively. The mean value of treated groups (hepatic fibrosis rats) G3, G4, G5, G6, G7 and G8 were lower than positive control group with a significant difference, which were $89.00 \pm 0.50,84.50 \pm 1.30$, $82.50 \pm 0.15,77.0 \pm 0.60,78.0 \pm 0.10$ and $70.50 \pm 0.30 \mathrm{mg} / \mathrm{dl}$, respectively. The best result for total cholesterol and triglycerides was recorded for (G8) rats fed on $5 \%$ palm date and apricot kernels mixture. These results are in agreement with Torres-Duran et al., (1998) they reported that levels of TG and TC in the liver also have been estimated to explain the status of liver. High level of TG and TC in the liver is the indication of the liver injury. They also indicated that TC and TG increased in $\mathrm{CCl}_{4}$-induced fatty liver. Yakubu et al., (2008), they reported that changes in the levels of major lipids such as cholesterol and triacylglycerol could provide useful information on the predisposition of the heart of animals to atherosclerosis and its associated coronary heart disease. A significant decrease in triacylglycerol may be associated with impaired lipolysis, although a reduction in HDL-C may not be clinically beneficial to animals at all doses tested, as the rate at which plasma cholesterol is transferred to the liver would also decrease. Abuelgassim, (2010) suggested that the lipid-lowering effect observed in dates palm might be due to it dietary fiber content. The result also suggests that date palm could have a protective effect against hyperlipidemia through improvement of lipids profile.

\section{Effects of palm date, apricot kernels powder and their mixtures on serum lipoprotein- cholesterol of hepatic fibrosis rats}

Results presented in Table (4) show the effect of palm date, apricot kernel and their mixtures on the serum lipoprotein - cholesterol of hepatic fibrosis rats. The results indicated that the HDL-c of negative control rats group recorded the higher value when compared with positive control group with significant difference at $(\mathrm{P} \leq 0.05)$. The mean values were $53.00 \pm 1.40$ and $30.50 \pm 1.20 \mathrm{mg} / \mathrm{dl}$, respectively. While, the mean value of treated groups (hepatic rats) G3, G4, G5, G6, G7 and G8 were 41.60 $\pm 0.50,44.50 \pm 0.30$, 
$45.50 \pm 1.20,48.50 \pm 1.15,47.40 \pm 1.50$ and $50.00 \pm 1.00 \mathrm{mg} / \mathrm{dl}$ and showed a significant difference when compared with positive control group.

As for LDL-c results showed that the mean value for positive control group was significantly higher than negative control group, which was $79.50 \pm 1.35$ and $29.40 \pm 0.11 \mathrm{mg} / \mathrm{dl}$, respectively. While, the mean value of treated groups (hepatic rats) G3, G4, G5, G6, G7 and G8 were $59.60 \pm 1.91, \quad 51.00 \pm 0.23,54.10 \pm 1.30,45.10 \pm 1.12,47.00 \pm 1.13$ and $36.90 \pm 1.10 \mathrm{mg} / \mathrm{dl}$ and showed a significant difference when compared with positive control group.

In case of VLDL-c, the positive control rats group recorded the highest value when compared with negative control group with a significant difference at $(\mathrm{P} \leq 0.05)$. The mean values were $20.00 \pm 1.10$ and $12.60 \pm 0.16 \mathrm{mg} / \mathrm{dl}$, respectively. While, the mean value of treated groups (hepatic fibrosis rats) G3, G4, G5, G6, G7 and G8 were $17.80 \pm 1.52, \quad 16.50 \pm 0.10, \quad 16.40 \pm 1.40, \quad 15.40 \pm 0.50, \quad 15.60 \pm 0.20, \quad$ and $14.10 \pm 1.20 \mathrm{mg} / \mathrm{dl}$ and showed a significant difference when compared with positive control group. The obtained results from Table (4) showed that group 8 which fed on 5\% palm date, apricot kernels mixture recorded the best result for lipid profile. These results are in agreement with Tanwar et al., (2018), they reported that blood lipid profile demonstrated that the detoxified apricot kernel group exhibited significantly $(p<0.05)$ increased levels of HDL-cholesterol $(48.79 \%)$ and triglycerides $(15.09 \%)$, and decreased levels of total blood cholesterol (6.99\%), LDL-C (22.95\%) and VLDL-C (7.90\%) as compared to that of the raw (untreated) kernels group. Overall, it can be concluded that wild apricot kernels flour could be detoxified efficiently by employing a simple, safe, domestic and cost-effective method, which further has the potential for formulating protein supplements and value-added food products. Also, Abdul-Aziz and Ali, (2014), stated that the lipid-lowering effect observed in dates palm extract might be due to it dietary fiber content and active compounds such as antioxidant. The result also suggests that date palm could have a protective effect against hyperlipidemia through improvement of lipid profile.

\section{Effect of palm date, apricot kernels powder and their mixtures on enzymes activities (GSH, SOD and CAT) level of hepatic fibrosis rats}

Results tabulated in Table (5) show the effect of palm date, apricot kernels and their mixtures as powders on enzymes activities (GSH, SOD and CAT) level of hepatic fibrosis rats. The obtained results indicated that the 
higher glutathione (GSH-Px) level recorded for negative control group, while the lower level recorded for positive control group with a significant difference $(\mathrm{P} \leq 0.05)$. The mean values were $230.00 \pm 2.32$ and $117.20 \pm 1.09 \mathrm{Ug}-{ }^{1}$ protein, respectively. While, the mean value of treated groups (hepatic rats) G3, G4, G5, G6, G7 and G8 were $135.10 \pm 1.17,155.30 \pm 1.11,165.50 \pm 1.13,181.50 \pm 1.14$, $175.50 \pm 1.15$, and $210.50 \pm 1.12 \mathrm{Ug}$ - ${ }^{1}$ protein and showed a significant difference when compared with positive control group.

As for SOD enzymes results showed that the mean value for negative control group was a significantly higher than positive control group, which was $24.00 \pm 0.02$ and $13.10 \pm 0.12$ Ug- ${ }^{1}$ protein, respectively. While, the mean value of treated groups (hepatic rats) G3, G4, G5, G6, G7 and G8 were $15.17 \pm 0.10,17.15 \pm 0.01,16.20 \pm 0.04$, $18.50 \pm 0.15, \quad 17.10 \pm 0.16$ and $20.13 \pm 0.03 \quad$ Ug- ${ }^{1}$ protein and showed a significant difference when compared with positive control group.

On the other hand, results of CAT enzymes showed that the mean value for negative control group was a significantly higher than positive control group, which was $203.00 \pm 0.15$ and $108.50 \pm 0.11 \mathrm{Ug}-{ }^{1}$ protein, respectively. While, the mean value of treated groups (hepatic rats) G3, G4, G5, G6, G7 and G8 were $140.0 \pm 0.20,145.0 \pm 0.01,160.0 \pm 0.31,168.0 \pm 0.01,165.90 \pm 0.51$ and $172.2 \pm$ $0.015 \mathrm{Ug}-{ }^{1}$ protein and showed a significant difference when compared with positive control group. These results agree with Gaeta et al., (2002); they reported that the antioxidant system involves both enzymatic and non-enzymatic agents. The first step in the enzymatic system is superoxide dismutase (SOD), which catalyzes the dismutation of superoxide anion $(\mathrm{O} \cdot 2)$ to $\mathrm{H}_{2} \mathrm{O}_{2}$. The conversion of $\mathrm{H}_{2} \mathrm{O}_{2}$ to $\mathrm{H}_{2} \mathrm{O}$ by either glutathione peroxidase (GPx) or catalase forms the second step of enzymatic system. Superoxide dismutase and GPx enzyme activities and the balance between them are very crucial for protection against oxidative stress. Increased activity of these antioxidant enzymes results in decreased formation of hydroxyl radical. Also, Abdel-Rahman (2011) mentioned that the diet supplemented with ground apricot kernel (GAK) led to improving liver function, lipid peroxides, and liver CAT, SOD and GSH. Hierarchically high levels of GAK $(1.5 \mathrm{mg} / \mathrm{kg} / \mathrm{BW} / \mathrm{rat})$ gave the best results compared to other tested levels. Abdul-Aziz and Ali, (2014), they reported that date palm (Phoenix dactylifera) seeds restored the activities of hepatic antioxidant enzymes (superoxide dismutase and glutathione S-transferase) that were declined after $\mathrm{CCl}_{4}$ treatment.

Karabulut et al., (2014) stated that bitter apricot kernel feeding had beneficial effects on $\mathrm{CCl}_{4}$-induced liver injury and damage probably due to its 
amygdaline contents and high radical-scavenging capacity. Dietary intake of amygdaline and bitter apricot kernels ratio of 5\% can reduce the risk of liver steatosis and damage caused by free radicals.

\section{Effect of palm date, apricot kernels powder and their mixtures on kidney functions of hepatic fibrosis rats}

Results presented in Table (6) show the effect of palm date, apricot kernel and their mixtures on kidney functions (urea, uric acid and creatinine) of hepatic rats. It is clear to notice that the urea level of positive control rats group recorded the higher value when compared with negative control group with significant difference at $(\mathrm{P} \leq 0.05)$. The mean values were $68.00 \pm 0.20$ and $32.00 \pm 1.10 \mathrm{mg} / \mathrm{dl}$, respectively. While, the mean value of G3, G4, G5, G6, G7 and G8 indicated a significant difference; it was $55.60 \pm 0.10,48.15 \pm 0.40$, $50.75 \pm 0.50,44.50 \pm 0.30,46.90 \pm 0.50$ and $36.60 \pm 0.31 \mathrm{mg} / \mathrm{dl}$, respectively when compared with positive control group.

On the other hand, the uric acid level of positive control rats group recorded the higher value when compared with negative control group with significant difference at $(\mathrm{P} \leq 0.05)$. The mean values were $3.10 \pm 0.10$ and $1.00 \pm 0.30 \mathrm{mg} / \mathrm{dl}$, respectively. While, the mean value of G3, G4, G5, G6, G7 and G8 indicated a significant difference; it was $1.85 \pm 0.30,1.50 \pm 1.50$, $1.80 \pm 0.40,1.34 \pm 0.60,1.45 \pm 1.40$ and $1.20 \pm 1.30 \mathrm{mg} / \mathrm{dl}$, respectively when compared with positive control group.

In case of creatinine level, the positive control rats group recorded the higher value when compared with negative control group with significant difference at $(\mathrm{P} \leq 0.05)$. The mean values were $64.00 \pm 0.50$ and $22.00 \pm 0.42$ $\mathrm{mg} / \mathrm{dl}$, respectively. While, the mean value of G3, G4, G5, G6, G7 and G8 indicated a significant difference; it was $56.00 \pm 3.04,51.35 \pm 1.20,46.50 \pm 1.30$, $38.10 \pm 1.50,36.50 \pm 1.40$ and $30.10 \pm 1.30 \mathrm{mg} / \mathrm{dl}$, respectively when compared with positive control group. The obtained results from Table (6) showed that group 8 which fed on 5\% palm date, apricot kernels mixture recorded the best result for kidney functions. These results are in agreement with Vardi et al., (2013), they reported that apricot diet had a clearly protective effect against lipid peroxidation and reduced renal MDA production. Also, they demonstrated that pretreatment apricot diet significantly decreased the apoptotic cell ratio when compared to the MTX-treated group. In similar studies, Huang et al., (2008) indicated that lipid peroxidation and impairment of antioxidant status may be involved in the sequence of events leading to methotrexate (MTX)induced renal damage. Additionally, increased serum creatinine and urea levels may reflect renal dysfunction and an activation of apoptotic cell markers, such as PARP, which also possibly contribute to MTX-caused kidney injury. Prophylactic administration of apricot may provide new therapeutic 
implications for the treatment of kidney diseases, which are characterized by apoptotic cell death and renal failure. Also, El-Mousalamy et al., (2016) reported that treatment with palm date fruit and seed aqueous and methanolic extracts caused significant improvement in kidney functions and morphology as evidenced by significant decrease in serum creatinine, urea, uric acid and urinary albumin excretion as well as significant reduction in glomerular and tubule interstitial damage scores compared to diabetic untreated rats. Palm date fruit and seed extracts protect the kidneys from diabetic nephropathy in rats that may be attributed to their antioxidant properties.

Finally, it could be observed that the higher the level of palm date kernels or apricot kernels in diets the more the desirable action on biological and biochemical parameters evaluated for hepatic fibrosis rats. All treatment groups revealed improvement of mentioned parameters, provided that the best group was that of $5 \%$ palm date, apricot kernels mixture diet. Over and above, no synergistic action, occurred when combining both fruits by-product together, provided that the mix palm date, apricot kernels diet revealed also some improvement Further research is required.

Table (1): Identification of phenolic compounds of apricot and palm date kernels

\begin{tabular}{|l|c|l|c|}
\hline apricot kernels & $\begin{array}{c}\text { Concentration } \\
\mathbf{m g} / \mathbf{1 0 0 g m}\end{array}$ & palm date kernels & $\begin{array}{c}\text { Concentration } \\
\mathbf{m g} / \mathbf{1 0 0 g m}\end{array}$ \\
\hline Gallic acid & 4.90 & Caffeic acid & 5.60 \\
\hline Procatechin acid & 3.10 & Rutin & 8.50 \\
\hline Chlorogenic acid & 917.00 & $\mathbf{( + ) - C a t e c h i n}$ & 7.68 \\
\hline Catechin & 2.30 & Vanillic acid & 0.30 \\
\hline Caffeic acid & 0.70 & Syringic acid & 0.83 \\
\hline Epicatechin & 2.50 & Gallic acid & 14.80 \\
\hline Quercetin & 12.60 & p-Coumaric acid & 1.95 \\
\hline Ferulic acid & 1.40 & Chlorogenic acid & ND \\
\hline Vanillin & 1.65 & Ferulic acid & ND \\
\hline p-coumaric acid & 3.77 & Epicatechin & ND \\
\hline
\end{tabular}


Table (2) Effect of palm date, apricot kernels powder and their mixtures on liver functions of hepatic fibrosis rats

\begin{tabular}{|c|c|c|}
\hline $\begin{array}{ll}\text { Groups } & \text { Parameters } \\
\end{array}$ & $\begin{array}{c}\text { AST } \\
\text { U/L }\end{array}$ & $\begin{array}{l}\mathbf{A L T} \\
\mathbf{U} / \mathbf{L}\end{array}$ \\
\hline $\mathbf{G}_{1} \mathbf{C}(-)$ & $50.10^{\mathrm{h}} \pm 0.80^{\mathrm{g}}$ & $47.20^{\mathrm{e}} \pm 0.10$ \\
\hline $\mathbf{G}_{2} \mathbf{C}(+)$ & $105.00^{\mathrm{a}} \pm 0.40$ & $93.50^{\mathrm{a}} \pm 0.35$ \\
\hline $\mathrm{G}_{3}(2.5 \%$ Palm date kernels) & $86.50^{b} \pm 1.20$ & $65.50^{b} \pm 0.45$ \\
\hline $\mathrm{G}_{4}(5 \%$ Palm date kernels) & $80.00^{\mathrm{c}} \pm 0.50$ & $60.00^{c} \pm 0.30$ \\
\hline $\mathrm{G}_{5}(2.5 \%$ Apricot kernels) & $76.85^{\mathrm{d}} \pm 0.90$ & $59.50^{c} \pm 0.15$ \\
\hline $\mathrm{G}_{6}(5 \%$ Apricot kernels $)$ & $68.50^{\mathrm{e}} \pm 0.60$ & $54.00^{\mathrm{d}} \pm 0.60$ \\
\hline $\mathrm{G}_{7}(2.5 \%$ Kernels mixture $)$ & $59.35^{\mathrm{f}} \pm 0.60$ & $52.00^{\mathrm{d}} \pm 0.50$ \\
\hline $\mathrm{G}_{8}(5 \%$ Kernels mixture $)$ & $53.75^{\mathrm{g}} \pm 0.60$ & $49.30^{\mathrm{e}} \pm 0.40$ \\
\hline LSD $(P \leq 0.05)$ & 2.35 & 2.26 \\
\hline
\end{tabular}

Each value represents the mean $\pm \mathrm{SD}$. Mean under the same column bearing different superscript letters are different significantly $(\mathrm{p} \leq 0.05)$.

Table (3): Effect of palm date, apricot kernel and their mixtures on total cholesterol and triglycerides of hepatic rats

\begin{tabular}{|c|c|c|}
\hline Groups $\quad$ Parameters & $\begin{array}{c}\text { Total } \\
\text { cholesterol } \\
\text { (TC) } \mathrm{mg} / \mathrm{dl}\end{array}$ & $\begin{array}{c}\text { Triglycerides } \\
\text { (TG) } \mathrm{mg} / \mathrm{dl}\end{array}$ \\
\hline$G_{1} C(-)$ & $95.00^{f} \pm 0.10$ & $63.00^{f} \pm 0.20$ \\
\hline $\mathbf{G}_{2} \mathbf{C}(+)$ & $130.00^{\mathrm{a}} \pm 1.40$ & $100.00^{\mathrm{a}} \pm 2.21$ \\
\hline $\mathrm{G}_{3}(2.5 \%$ Palm date kernels $)$ & $119.00^{b} \pm 0.30$ & $89.00^{b} \pm 0.50$ \\
\hline $\mathrm{G}_{4}(5 \%$ Palm date kernels) & $112.00^{\mathrm{d}} \pm 0.10$ & $84.50^{c} \pm 1.30$ \\
\hline $\mathrm{G}_{5}(2.5 \%$ Apricot kernels) & $116.00^{\mathrm{c}} \pm 0.30$ & $82.50^{c} \pm 0.15$ \\
\hline $\mathrm{G}_{6}(5 \%$ Apricot kernels) & $109.00^{\mathrm{d}} \pm 0.40$ & $77.00^{\mathrm{d}} \pm 0.60$ \\
\hline$G_{7}(2.5 \%$ Kernels mixture $)$ & $110.00^{\mathrm{d}} \pm 0.20$ & $78.00^{\mathrm{d}} \pm 0.10$ \\
\hline $\mathrm{G}_{8}(5 \%$ Kernels mixture $)$ & $101.00^{\mathrm{e}} \pm 0.30$ & $70.50^{\mathrm{e}} \pm 0.30$ \\
\hline LSD $(P \leq 0.05)$ & 3.602 & 3.425 \\
\hline
\end{tabular}

Each value represents the mean $\pm \mathrm{SD}$.

Mean under the same column bearing different superscript letters are different significantly $(\mathrm{p} \leq 0.05)$. 
Table (4): Effect of palm date, apricot kernels and their mixtures on lipid profile of hepatic rats

\begin{tabular}{|c|c|c|c|}
\hline $\begin{array}{ll}\text { Groups } & \text { Parameters } \\
\end{array}$ & $\begin{array}{c}\text { (HDL-c) } \\
(\mathrm{mg} / \mathrm{dl})\end{array}$ & $\begin{array}{l}\text { (LDL-c) } \\
(\mathrm{mg} / \mathrm{dl})\end{array}$ & $\begin{array}{l}\text { (VLDL-c) } \\
(\mathrm{mg} / \mathrm{dl})\end{array}$ \\
\hline$G_{1} C(-)$ & $53.00^{\mathrm{a}} \pm 1.40$ & $29.40^{\mathrm{g}} \pm 0.11$ & $12.60^{\mathrm{d}} \pm 0.16$ \\
\hline $\mathbf{G}_{2} \mathbf{C}(+)$ & $30.50^{\mathrm{e}} \pm 1.20$ & $79.50^{\mathrm{a}} \pm 1.35$ & $20.00^{\mathrm{a}} \pm 1.10$ \\
\hline $\mathrm{G}_{3}(2.5 \%$ Palm date kernels) & $41.60^{\mathrm{d}} \pm 0.50$ & $59.60^{\mathrm{b}} \pm 1.91$ & $17.80^{b} \pm 1.52$ \\
\hline $\mathrm{G}_{4}(5 \%$ Palm date kernels $)$ & $44.50^{c} \pm 0.30$ & $51.00^{\mathrm{d}} \pm 0.23$ & $16.50^{b} \pm 0.10$ \\
\hline$G_{5}(2.5 \%$ Apricot kernels $)$ & $45.50^{\mathrm{c}} \pm 1.20$ & $54.10^{\mathrm{c}} \pm 1.30$ & $16.40^{b} \pm 1.40$ \\
\hline $\mathrm{G}_{6}(5 \%$ Apricot kernels) & $48.50^{b} \pm 1.15$ & $45.10^{\mathrm{e}} \pm 1.12$ & $15.40^{b c} \pm 0.50$ \\
\hline $\mathrm{G}_{7}(2.5 \%$ Kernels mixture $)$ & $47.40^{\mathrm{bc}} \pm 1.50$ & $47.00^{\mathrm{e}} \pm 1.13$ & $15.60^{\mathrm{bc}} \pm 0.20$ \\
\hline $\mathrm{G}_{8}(5 \%$ Kernels mixture $)$ & $50.00^{\mathrm{b}} \pm 1.00$ & $36.90^{\mathrm{f}} \pm 1.10$ & $14.10^{\mathrm{d}} \pm 1.20$ \\
\hline LSD $(P \leq 0.05)$ & 2.421 & 2.74 & 2.02 \\
\hline
\end{tabular}

Each value represents the mean $\pm \mathrm{SD}$.

Mean under the same column bearing different superscript letters are different significantly $(\mathrm{p} \leq 0.05)$.

Table (5) Effect of palm date, apricot kernels powder and their mixtures on enzymes activity level of hepatic fibrosis rats

\begin{tabular}{|c|c|c|c|}
\hline $\begin{array}{l}\text { Parameters } \\
\text { Groups }\end{array}$ & $\begin{array}{c}\text { GSH } \\
\text { (Ug-1 }{ }^{1} \text { protein) }\end{array}$ & $\begin{array}{c}\text { SOD } \\
\text { (Ug-1 protein) }\end{array}$ & $\begin{array}{c}\text { CAT } \\
\text { (Ug-1 }{ }^{1} \text { protein) }\end{array}$ \\
\hline$G_{1} C(-)$ & $230.0^{\mathrm{a}} \pm 2.32$ & $24.00^{\mathrm{a}} \pm 0.02$ & $203.0^{\mathrm{a}} \pm 0.15$ \\
\hline $\mathbf{G}_{2} \mathbf{C}(+)$ & $117.20^{\mathrm{h}} \pm 1.09$ & $13.10^{\mathrm{f}} \pm 0.12$ & $108.5^{\mathrm{g}_{ \pm}}+0.11$ \\
\hline $\mathrm{G}_{3}(2.5 \%$ Palm date kernel $)$ & $135.10^{\mathrm{g}} \pm 1.17$ & $15.17^{\mathrm{e}} \pm 0.10$ & $140.0^{\mathrm{f}} \pm 0.20$ \\
\hline $\mathrm{G}_{4}(5 \%$ Palm date kernels) & $155.30^{\mathrm{f}} \pm 1.11$ & $17.15^{\mathrm{d}} \pm 0.01$ & $145.4^{\mathrm{e}} \pm 0.01$ \\
\hline$G_{5}(2.5 \%$ Apricot kernels $)$ & $165.50^{\mathrm{e}} \pm 1.13$ & $16.20^{\mathrm{d}} \pm 0.04$ & $160.1^{\mathrm{d}} \pm 0.31$ \\
\hline $\mathrm{G}_{6}(5 \%$ Apricot kernels) & $181.50^{\mathrm{c}} \pm 1.14$ & $18.50^{c} \pm 0.15$ & $168.0^{c} \pm 0.01$ \\
\hline$G_{7}(2.5 \%$ Kernels mixture $)$ & $175.50^{\mathrm{d}} \pm 1.15$ & $17.10^{\mathrm{d}} \pm 0.16$ & $165.9^{c} \pm 0.51$ \\
\hline $\mathrm{G}_{8}(5 \%$ Kernels mixture $)$ & $210.50^{b} \pm 1.12$ & $20.13^{\mathrm{b}} \pm 0.03$ & $172.2^{\mathrm{b}} \pm 0.015$ \\
\hline LSD (P $\leq \mathbf{0 . 0 5})$ & 4.751 & 1.237 & 4.021 \\
\hline
\end{tabular}

Each value represents the mean $\pm \mathrm{SD}$.

Mean under the same column bearing different superscript letters are different significantly ( $\mathrm{p} \leq 0.05)$. 
Table (6): Effect of palm date, apricot kernels and their mixtures on kidney functions of hepatic fibrosis rats

\begin{tabular}{|c|c|c|c|}
\hline$\overbrace{\text { Groups }}$ Parameters & $\begin{array}{l}\text { Urea } \\
\mathrm{mg} / \mathrm{dl}\end{array}$ & $\begin{array}{l}\text { Uric acid } \\
\mathrm{mg} / \mathrm{dl}\end{array}$ & $\begin{array}{l}\text { Creatinine } \\
\text { mg/dl }\end{array}$ \\
\hline$G_{1} C(-)$ & $32.00^{f} \pm 1.10$ & $1.00^{\mathrm{c}} \pm 0.30$ & $22.20^{\mathrm{g}_{ \pm}} 0.42$ \\
\hline $\mathbf{G}_{2} \mathbf{C}(+)$ & $68.00^{\mathrm{a}} \pm 0.20$ & $3.10^{\mathrm{a}} \pm 0.10$ & $64.00^{\mathrm{a}} \pm 0.50$ \\
\hline $\mathrm{G}_{3}(2.5 \%$ Palm date kernels $)$ & $55.60^{b} \pm 0.10$ & $1.85^{\mathrm{b}} \pm 0.30$ & $56.00^{\mathrm{b}} \pm 3.04$ \\
\hline $\mathrm{G}_{4}(5 \%$ Palm date kernels) & $48.15^{\mathrm{c}} \pm 0.40$ & $1.50^{\mathrm{b}} \pm 1.50$ & $51.35^{\mathrm{c}} \pm 1.20$ \\
\hline$G_{5}(2.5 \%$ Apricot kernels) & $50.75^{c} \pm 0.50$ & $1.80^{\mathrm{b}} \pm 0.40$ & $46.50^{\mathrm{d}} \pm 1.30$ \\
\hline$G_{6}(5 \%$ Apricot kernels) & $44.50^{\mathrm{d}} \pm 0.30$ & $1.34^{\mathrm{b}} \pm 0.60$ & $38.10^{\mathrm{e}} \pm 1.50$ \\
\hline$G_{7}(2.5 \%$ Kernels mixture $)$ & $46.90^{\mathrm{d}} \pm 0.50$ & $1.45^{\mathrm{b}} \pm 1.40$ & $36.50^{\mathrm{e}} \pm 1.40$ \\
\hline G $_{8}(5 \%$ Kernels mixture) & $36.60^{\mathrm{e}} \pm 0.31$ & $1.20^{\mathrm{b}} \pm 1.30^{\mathrm{c}}$ & $30.10^{\mathrm{f}} \pm 1.30$ \\
\hline LSD $(\mathrm{P} \leq 0.05)$ & 2.80 & 0.75 & 2.93 \\
\hline
\end{tabular}

Each value represents the mean \pm SD.

Mean under the same column bearing different superscript letters are different significantly $(\mathrm{p} \leq 0.05)$.

\section{References}

Abdul-Aziz, D. and Ali, S. (2014): The protective effect of Phoenix dactylifera, L. seeds against $\mathrm{CCl}_{4}$-induced hepatotoxicity in rats. J. of Ethnopharm., 155 (1): 736-743.

Abdel-Rahman, M.K. (2011): Can apricot kernels fatty acids delay the atrophied hepatocytes from progression to fibrosis in dimethyl nitrosamine $(\mathrm{DMN})$-induced liver injury in rats. Lipids in Health and Disease, 10 (114): 210.

Abuelgassim, A.O. (2010): Effects of flax seed and date palm leaves extract on serum concentration of glucose and lipids in alloxan diabetic rats. J. of Biol. Sci., 13: 1141-1145. 
AIN (1993): American institute of nutrition purified diet for laboratory Rodent, Final Report. J. Nutrition, J. Essential Oil Res., 8 (6): 657-664.

Al-Farsi, M.; Alasalvar, C.; Al-Abid, M.; Al-Shoaily, K.; Al-Amry, M. AlRawahy, F. (2007): Compositional and functional characteristics of dates, syrups, and their by-products. Food Chem., 104 (3): 943-947.

Al-Harbi, N.O.; Imam, F.; Nadeem, A.; Al-Harbi, M.M.; Iqbal, M. and Ahmad, S.F. (2014): Carbon tetrachloride-induced hepatotoxicity in rat is reversed by treatment with riboflavin. Int. Immunopharmacol, 21: 383-388.

Ahmed, M.B.; Hasona, N.A. and Selemain, H.A. (2008): Protective effects of extract from dates (Phoenix Dactylifera, L.) and ascorbic acid on thioacetamide-induced hepatotoxicity in rats. Iranian J. Pharm. Res. 7 (3): 193201.

Alpaslan, M. and Hayta, M. (2006): Apricot kernel: Physical and chemical properties. J.of the Amer. Oil Chem. Soc., 83 (5): 469-471.

Barham, D. and Trinder, P. (1972): Determination of uric acid. Analyst, 97: 142.

Clinica Chimica Acta (1980): Chemical kits.105: 147-172.

Crawford, J.M. (2007): Basic mechanism in hepatopathology. In: Roderick, N.M., Burt, D.A., Portmann, B., Ferrell, L.D. (Eds.), Pathology of the Liver. Fifth ed. Churchill Livingstone, Elsevier, pp. 119-146.

Diao, Y.; Zhao, X.F.; Lin, J.S.; Wang, Q.Z. and Xu, R.A. (2011): Protection of the liver against $\mathrm{CCl}_{4}$-induced injury by intramuscular electrotransfer of a kallistatin-encoding plasmid. World J. Gastroenterol, 17: 111-117.

Dicenta, F.; Martínez-Gómez, P.; Grané, N.; Martín, M.L. and León, A. (2002): Relationship between cyanogenic compounds in kernels, leaves, and roots of sweet and bitter kernelled almonds. J. Agric. Food Chem., 50: 21492152.

Dong, C. Z.; Jun, X. L.; Rui, C.; Wei, H. Y.; Xiu, M. Z.; Shu, N.L. and Peng, X. (2005): Bone marrow derived mesenchymal stem cells protect against experimental liver fibrosis in rats. World J. Gastroenterol., 11 (22): 3431-3440.

El-Far, A. H.; Shaheen, H.M.; Abdel-Daim, M.M.; Al-Jaouni, S.K. and Mousa, S.A. (2016): Date Palm (Phoenix dactylifera): protection and Remedy Food. Current Trends in Nutraceuticals, 2 (9): 1-10.

El-Mousalamy, A.M.; Hussein, A.A.; Mahmoud, S.A.; Abdelaziz, A. and Shaker, G. (2016): Aqueous and Methanolic Extracts of Palm Date Seeds and Fruits (Phoenix dactylifera,) Protects against Diabetic Nephropathy in Type II Diabetic Rats. Biochem. Physiol, 5 (2): 1-9.

Femenia, A.;Rossell, C.;Mulet,A. and Jaime Caiiellas,J. (1995): Chemical composition of bitter and sweet apricot kernels.J. Agric.Food Chem.,43:356361.

Fossati, P. and Principle, I. (1982): Chemical Kits. Clin. Chem., 28: 2077. 
Friedwaid, W.T. (1972): Determination of HDL. Clin. Chem. 18: 499.

Gaeta, L.M.; Tozzi, G.; Pastore, A.; Federici, G. and Piemonte, F. (2002): Determination of superoxide dismutase and glutathione peroxidase activities in blood of healthy pediatric subject. Clin Chim Acta, 322: 117-120.

Ganesan, K.; Jayachandran, M. and Xu, B. (2018): A critical review on hepatoprotective effects of bioactive food components. Critical Reviews in Food Science and Nutrition, 58 (7): 1165-1229.

Ghany, M. and Hoofnagle, J.H. (2005): Approach to the patient with liver disease. In: Kasper, D.L., Braunwald, E., Fauci, A.S., Hauser, S.L., Longo, D.L., Jameson, J.L. (Eds.), sixteenth ed. Harrison's Principles of Internal Medicine, vol. 2. McGraw Hill, New York, pp. 1808-1813.

Goth, L. (1991): A simple method for determination of serum catalase activity and revision of reference range. Clin. Chim. Acta, 196:143-152.

Grodon, T. and Amer, M. (1977): Determination of HDL. Clin. Chem., 18: 707.

Hafkenscheid, J.C. (1979): Determination of GOT. Clin. Chem., 25:155.

Henry, R.J. (1974): Clinical Chemist: Principles and Techniques, $2^{\text {nd }}$ Edition, Hagerstoun (MD), Harcer, ROW, P. 882.

Huang, S.M.; Chuang, H.C.; Wu, C.H. and Yen, G.C. (2008): Cytoprotective effects of phenolic acids on methylglyoxal-induced apoptosis in Neuro-2A cells. Mol. Nutr. Food Res., 52: 940-949.

Karabulut, B.; Önal, Y.; Gül, M.; Otlu, O.; Tuzcu, M.; Semir Gül, S. and Sahin, S. (2014): Nutri-protection and Mediterranean diet: Bitter apricot kernel and amygdalin treatment effects on a battery of oxidative stress and apoptosis biomarkers. J. Plant Physiol. Pathol., 2 (3): 2-6.

Lee, R. and Nieman, D. (1996): Nutrition Assessment. $2^{\frac{\text { nd }}{1}}$ Ed., Mosby, Missouri, MI.

McCord, J.M. and Fridovich, I. (1969): Superoxide dismutase. An enzymic function for erythrocuprein (hemocuprein). J. Biol. Chem., 244: 6049-6055.

Moss, D.W. (1982): Alkaline phosphatase isoenzymes. Clin. Chem., 28: 20072016.

Ohta, Y.; Nishimura, M. and Matsura, T. (2004): Melatonin prevents disruption of hepatic reactive oxygen species metabolism in rats treated with carbon tetrachloride. J. Pineal. Res., 36: 10-17.

Paglia, D.E. and Valentine, W.N. (1967): Studies on the quantitative and qualitative characterization of erythrocyte glutathione peroxidase. J. Lab. Clin. Methods, 2: 158-169.

Patton, C.J. and Crouch, S.R. (1977): Enzymatic determination of urea. J. of Anal. Chem., 49: 464-469.

Radovanović, B.C.; Radovanović, A.N. and Souquet, J.M. (2010): Phenolic profile and free radical-scavenging activity of Cabernet Sauvignon wines of 
different geographical origins from the Balkan region. J. Sci. Food Agric., 90, 2455-2461.

Reeves, P.; Nielsen,F. and Fahmy,G.(1993): Purified diets for laboratory rodents: Final report of the American Institute of Nutrition ad Hoc writing committee on the reformulation of the AIN-76 a rodent diet. J. Nutr., 123:19391951.

Saleh, E.A.; Tawfik, M.S. and Abu-Tarboush, M.H. (2011): Phenolic contents and antioxidant activity of various date palm (Phoenix dactylifera, L.) fruits from Saudi Arabia. Food and Nut. Sci., 2: 1134-1141.

SAS (1988): SAS Users Guide: Statistics version $5^{\text {th }}$ Ed. SAS. Institute Inc., Cary N.C.

Schermer, S. (1967): The Blood Morphology of Laboratory Animal. Longmans Printed in Great Britain, Green and Co. Ltd, p. 350.

Tanwar, B.; Modgil, R. and Goyal, A. (2018): Anti-nutritional factors and hypocholesterolemic effect of wild apricot kernel (Prunus armeniaca, L.) as affected by detoxification. Food Funct., 9: 2121-2135.

Thomas, L. (1992): Labor and Diagnose, $4^{\text {th }}$ Ed., (Chemical Kits).

Torres-Duran, P.V.; Miranda-Zamora, R.; Paredes-Carbajal, M.C.; Mascher, D.; Daaz-Zagoya, J.C. and Juarez-oropeza, M.A. (1998): Spirulina maxima prevents induction of fatty liver by carbon tetrachloride in the rat. Biochem. Mol. Biol. Int., 44: 787-793.

Ugur, Y, Erdoğan S, Yilmaz İ. (2018): Variation of quantitative composition nus armeniaca L. (apricot) on low dose radiation-1nduced kidney damage in rats. Turk Neph Dial Transpl. 2018;23(2):105-111.

Vardi, N.; Parlakpinar, H.; Ates, B.; Cetin, A. and Otlu, A. (2013): The protective effects of Prunus armeniaca, L (apricot) against methotrexateinduced oxidative damage and apoptosis in rat kidney. J. Physiol. Biochem., 69: 371-381.

Vayalil, P.K. (2012): Date fruits (Phoenix dactylifera, linn) an emerging medicinal food. Crit. Rev. Food. Sci. Nutr., 52: 249-271.

Vuda, M.; Souza, R.D. and Upadhya, S. (2012): Hepatoprotective and antioxidant activity of aqueous extract of Hybanthus enneaspermus againstCCl4-induced liver injury in rats. Exp. Toxicol. Pathol., 64 (7-8): 855859.

Yakubu, M.T.; Akanji, M.A. and Oladiji, A.T. (2008): Alterations in serum lipid profile of male rats by oral administration of aqueous extract of Fadogia agrestis stem. Res. J. Med. Plant., 2: 66-73.

Young, D.S. (1975): Determination of GOT. Clin. Chem., 22 (5): 1- 21. 


\section{التأثير الوقائي للكبد لمسحوق بذور المشمش والبلح على اضطرابات الكبد فى الفئران}

\section{المستحث برابع كلوريد الكريون}

تم دراسـة تأثثر تركيزات مختلفةه ب و ه ٪ من نوى المشمش والبلح ومخلوتهم كمسحوق على التغيرات البيولوجية والكيميائية الحيوية للجرذان المصابة بالتليف الكبدي. في هذه الدراسة تم استخدام

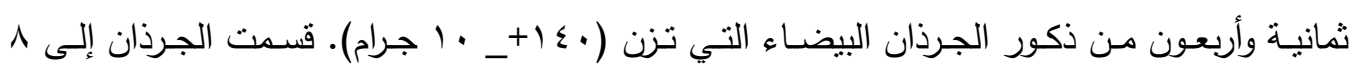
مجموعات، كل مجموعة بها (آ) فئران. تم احداث الإصابة بالتليف الكبدي في الجرذان عن طريق حقن

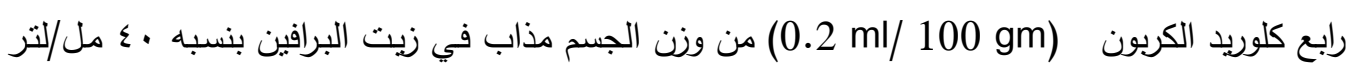
من رابع كلوريد الكربون ـ تم تحديد التعرف على المركبات الفينولية في نوى المشمش والبلح بجهاز الكروماتوجرافى عالي الأداء، أنزيمات الكبد في الدم مثل الانين امينو ترانسفيراز (ALT) و و اسبارنات امينو ترانسفيراز (AST) ، والكوليسترول الكلى والجليسيردات الثثلاثية، الكوليسترول المرتفع الكثافه، الكوليسترول المنخفض الكثافة، الكوليسترول المنخفض جدا الكثافة، وظائف الكلي ( حمض البوليك، اليوريا، الكرياتينين)، ونشاط الانزيمات المؤكسدة مثل الجلوتاثيون أوكسيديز، سوبر أوكسيد ديسميوتيز ،

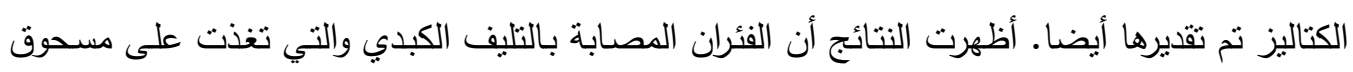
نوى المشم والبلح ومخلوطهم معا أدت إلى حدوث تحسن ملحوظ في كلا من مستويات وظائف الكبد والكلى وصورة دهون الدم ونشاط الانزيمات المؤكسدة في الجرذان خصوصـا التي تغذت على مخلوط

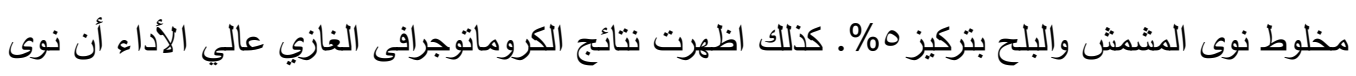

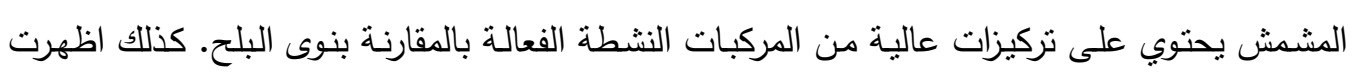
النتائج أيضـا أن مخلوط نوى المشمش والبلح سجل أفضل معلى معاملـه لتحسين جميع التحاليل الكيميائية الحيوية المختبرة. لذا يمكن استخدام مسحوق نوى المشمش والبلح ومخلوطهم معا في مشروباتتا وأطباقنا اليومية لما له من فوائد صحية كثثره. الكلمات المفتاحية: نوى المشمش - نوى البلح ـ الجرذان ـ التأثير الواقي - التحاليل البيوكيميائية. 